\title{
DE SURINAAMSCHE GRONDBRIEVEN TEN TIJDE VAN GOUVERNEUR VAN AERSSEN VAN SOMMELSDIJCK.
}

\author{
DOOR
}

MR. R. BIJLSMA.

Evenals in de Zeeuwsche bestuursperiode bleef ook in het tijdperk van de Societeit van Suriname de gouverneur der kolonie de autoriteit, die de bevoegdheid had tot het uitgeven van gronden. De instructie, in 1683 voor gouverneur Van Aerssen van Sommelsdijck vastgesteld, gaf daarover in de artikelen $17-18$ de volgende voorschriften: de gouverneur mocht niet meer grond uitgeven, dan de opnemer ervan in cultuur zou kunnen brengen; de breedte van den uit te geven grond zou langs de rivier niet grooter mogen zijn dan noodig was voor het transport der producten, zoodat langs de oevers plaats overbleef voor andere plantages; indien planters de bepalingen der Staten van Zeeland op dit punt reeds overtreden hadden, zouden maatregelen tegen hen moeten worden genomen ${ }^{1}$ ). Ingevolge deze voorschriften stelde Gouverneur Van Aerssen bij placaat van 7 Juli 1684 vast, dat de landmeters in de kolonie geen grooter plantages zouden mogen uitmeten dan 1000 akkers of 10.000 vierkante kettingen en dat op iedere ketting langs de rivier de grond zich 100 kettingen landwaarts in zou uitstrekken. Het volgende jaar werd de breedte der gronden langs de rivier aanmerkelijk verminderd, doordat de Gouverneur bij placaat van 24

1) Notulen Directeuren Societeit 9 Juli 1683. De instructie is gedrukt als bijlage tot de Consideratien van Bewindhebbers W. I. C. over de directie der Colonie Suriname en het gouvernement van den Heer van Sommelsdijck. 
Mei 1685 gelastte, dat voor plantages, sedert 1 Januari van dat jaar uitgegeven, de grond slechts 60 kettingen langs de rivier zou mogen meten, waartegen de diepte 160 kettingen zou komen te beloopen.

De voorwaarden, door Gouverneur Van Aerssen van Sommelsdijck aan de uitgifte van gronden in de kolonie verbonden, leeren wij kennen uit enkele warrants of grondbrieven uit zijn bestuurstijdperk, die in afschrift bewaard zijn gebleven in het archief der Societeit van Suriname ${ }^{\mathbf{1}}$ ). Deze warrants waren als volgt geformuleerd:

„Wij Cornelis van Aerssen van Sommelsdijck, heere van Sommelsdijck enz., Gouverneur-Generael van de Colonie van Suriname, rivieren en districten van dien,

Vergunnen en permitteeren mits desen aan N.N. omme op te nemen ende in vrijen eigendom te besitten de nombre van.... ackers landt gelegen in de rivier van.... ofte ter plaetse daer hij raetsaem sal vinden, mits betalende alle jaeren een stuiver per acker, ende deselve te besitten den tijd van twaelff jaeren sonder die te moghen vercoopen ofte veralineeren dan met particulier consent van den heer Gouverneur, ende de twaelff jaeren geexpireert sijnde in cas van vercoopinge te betalen vijf percento, ende indien consent van den heere Gouverneur gekreegen hebbende omme de voorzegde landen binnen de twaelf jaeren te vercoopen, soo sal denselven gehouden zijn te betaelen tien percento ten profyte van de Societeyt, behoudende en reserveerende den heer Gouverneur het recht van naestinge ten profijte als als boven; mits niet doende tot nadeel van de Indianen (onse vrinden) ${ }^{2}$ ) ofte eenige vorige concessie; welcke landen binnen een jaer en ses weecken moeten werden gecultiveert met ten minsten van een getal van.... slaven en door den landtmeeter uytgemeeten binnen den tijt van drie maenden naer dato deses op pene van versteecken, ten ware dat hij den lantmeeter daertoe

$\left.{ }^{r}\right)$ Brieven en Papieren uit Suriname aan Directeuren Societeit 1685 I, fol. $177 ; 1687$ I, fol. 302.

) Bijgevoegd sedert 1685 . 
meermale hadde aengesproocken, en hij hetselvige niet connende doen, soo sal op de voorzegde drie maenden geen reflectie genomen worden mits thonende soodanigen attestatie van de hant van den lantmeeter; laetende deselve uytgemeeten sijnde, ter behoorlijcker tijt alhier ter secretarije registreeren".

Tegen deze voorwaarden van gronduitgifte rezen bezwaren van de zijde van Raden van Politie in de kolonie; naar hunne meening liet het Octrooi betreffende Suriname van 1682 de jaarlijksche heffing van een akkergeld niet toe en bovendien verzetten zij zich tegen de belemmering van overdracht binnen de eerste twaalf jaren en het naastingsrecht, dat de Gouverneur zich voorbehield. Ter wederlegging wees Gouverneur van Aerssen van Sommelsdijck er onder meer op, dat de heffing van akkergeld niet te beschouwen was als belasting, en dat de Societeit van Suriname, als eigenares der kolonie, het recht had naar goeddunken over hare gronden te disponeeren en deze op thijns of akkergeld uit te geven ${ }^{\mathbf{1}}$ ).

Bij de mededeeling hunner bezwaren aan Directeuren der Societeit voegden Raden van Politie een brief van gronduitgifte, zooals deze in de Zeeuwsche periode tijdens het Gouvernement van Pieter Versterre placht te worden gesteld; dusdanige warrant hield vergunning in ,op te nemen ende in vrijen eigendom te bezitten een stuck landt groot.... ackers, waer hij hetselve bequaem sal vinden, mits niet doende tot nadeel van d'Indiaenen ofte eenige vorige concessie, ende sal 't selve ter behoorlijcker tijt ter secretarye laten prothocolleren". ${ }^{2}$ ) Deze vorm van uitgifte heeft, met een geringe toevoeging, geduurd tot het einde van het Zeeuwsche tijdperk; dit blijkt uit een warrant van Maart 1683, die bovendien als voorwaarde stelt het in cultuur brengen van het land binnen 1 jaar en 6 weken $^{3}$ ). Verklaringen van twee

${ }^{1}$ ) Notulen Gouverneur en Raden van Politie 7 Maart 1685 (in Brieven uit Suriname 1685 I fol. 169).

$\left.{ }^{2}\right)$ Brieven uit Suriname 1685 I fol. 176.

3) Deze warrant is te vinden in de stukken betreffende Surinaamsche plantages der familie Van Gelre (Aanwinsten Algem. Rijksarchief 1888 A. nummer 3d.). 
getuigen en den landmeter betreffende de opneming en uitmeting van het land zijn later op dezen warrant bijgeschreven.

De verplichting tot betaling van akkergeld is in deze uitgiftebrieven niet opgenomen. Toch staat het vast, dat gedurende het Zeeuwsche tijdperk akkergeld betaald werd, zoowel tijdens het gouvernement Versterre als nog in $1683^{1}$ ). Voor de heffing van een akkergeld vinden wij trouwens aanknoopingspunten bij de Engelsche periode. Onmiddellijk na de bestuursaanvaarding van Gouverneur Lichtenberg in Februari 1669 vaardigde deze een placaet uit, waarbij aan de ingezetenen gelast werd over te leggen de eigendomsbewijzen van hun land met de kwitantiën van betaling der taxatien daarvoor aan het Engelsche koloniale gouvernement, en op te geven het aantal gemeten of ackers land, dat zij bezaten en beplantten ${ }^{2}$ ).

De verwijzing, door Raden van Politie in 1685 gedaan naar de Zeeuwsche voorwaarden van gronduitgifte, mocht hun niet baten. Directeuren der Societeit bleven de zaak in beraad houden en Gouverneur Van Aerssen van Sommelsdijck ging op denzelfden voet door met het uitgeven van grond ${ }^{3}$ ). Verandering hierin kwam eerst onder zijn opvolger Van Scharphuysen, van wien bekend zijn vergunningen uit de jaren 1690 en 1691 tot het,opnemen in allodialen eigendom en erfelijk bezitten" van grond onder geen andere voorwaarde, dan dat men het land binnen 1 jaar en 6 weken in cultuur zou brengen ${ }^{4}$ ).

\footnotetext{
1) Lijsten van akkergelden over $1680-1683$ in Brieven uit Suriname 1685 I fol. 195. Zie ook Encycl. Ned. W.-Indië p. 769.

$\left.{ }^{2}\right)$ De Surinaamsche acker is de Engelsche acre; een acker of gemet is $1 / 2$ Rijnlandsche morgen of $10 \square$ kettingen; ketting is de Engelsche chain van 66 feet.

Ook voor andere Surinaamsche termen kan de oorsprong teruggebracht worden tot het Engelsche administratieve gebruik; te noemen zijn: warrant, facie (van de rivier), trens, effect, prisatie, court, jurator enz.

3) Warrant van December 1687 in Brieven uit Suriname 1732 fol. 729.

4) Warrants van 1690 en 1691 in Brieven uit Suriname 1732 fol. 727 en 1696 fol. 352.
} 